Research article

\title{
COMPARISON OF RESORBABLE MEMBRANES FOR GUIDED BONE REGENERATION OF HUMAN AND BOVINE ORIGIN
}

\author{
LAZIĆ Zoran ${ }^{1}$, BUBALO Marija ${ }^{1 *}$, MLOVIĆ Radomir ${ }^{1}$, MATIJEVIĆ Stevo ${ }^{1}$, \\ MAGIĆ Marko ${ }^{1}$, ĐORĐEVIĆ Igor ${ }^{2}$
}

${ }^{1}$ Clinic for Dentistry Military Medical Academy, Belgrade, Serbia; ${ }^{2}$ Faculty of Dentistry, Belgrade, Serbia

(Received 13 February; Accepted 06 May 2014)

The properties of membranes for guided bone regeneration have been described by a number of authors. These involve biocompatibility, appropriate barrier features (mechanical prevention of soft tissue proliferation), tissue integration, immunologic neutrality, preservation of the space for new alveolar bone, and simplicity of application. Such membrane must hold out against the masticatory forces and tissue tension of the flap, and prevent the collapse of soft tissues and wound space reduction. The property of integration into the tissue guarantees wound stabilization and inhibits epithelial migration.

The aim of this study was to compare and evaluate the influence of human resorbable demineralized membrane (RHDM) and bovine resorbable demineralized membrane $(\mathrm{RBDM})$ on bone regeneration.

The experiment, approved by the Ethical Committee, was performed on six dogs and conducted into three phases. Bone defects were created in all six dogs on the left side of the mandible, 8 weeks after extraction of the second, third and fourth premolar. One defect was covered with $200 \mu \mathrm{m}$ thick RHDM, one with $200 \mu \mathrm{m}$ thick RBDM, and the third defect was left empty (control defect). The pathohistological analysis was done two, four and six months after the surgery. In the third phase samples of bone tissue were taken and subjected to patohistological analysis.

In all six dogs the defects treated with RHDM $200 \mu \mathrm{m}$ thick showed a higher level of bone regeneration in comparison with the defect treated with RBDM $200 \mu \mathrm{m}$ thick and especially with the control defect.

Our results demonstrated that the human membrane showed the least soft tissue ingrowth and promoted better bone formation at 6 months compared with a bovine one.

Key words: bovine resorbable membrane, dog mandible defect, guided bone regeneration, human resorbable membrane, membrane thickness

Corresponding author: e-mail: bubalo.marija@yahoo.com 


\section{INTRODUCTION}

For both the esthetic outcome and long-term success, a sufficient amount of living bone is required to place an endosseous dental implant in the jawbone. In about $50 \%$ of implant sites, however, there is a need for a procedure that predictably generates enough bone volume for the placement of a dental implant. There are several options for the enhancement of bone formation, including: osteoinduction by bone grafts or growth factors [1]; osteoconduction by bone grafts or substitute materials that serve as a scaffold for new bone formation [2]; transfer of stem cells or progenitor cells that differentiate into osteoblasts; distraction osteogenesis $[3,4]$ and guided bone regeneration (GBR) using barrier membranes $[5,6]$. There is always an underlying basic mechanism of bone healing.

GBR, usually in combination with grafting material, is the method widely used to augment bone in routine dental practice. Because bone is a relatively slow-growing tissue, both fibroblasts and epithelial cells have the opportunity to occupy the available space more efficiently and build up a soft connective tissue much faster than bone is able to grow. An important cornerstone of GBR has been the placement of a barrier membrane between the osseous defect requiring bone augmentation and the adjacent gingival tissues. Thus, the biologic mechanism behind GBR is the exclusion of undesirable cells from the wound environment to enable cells from the bone tissue to proliferate into the coagulum-filled space under the barrier membrane. If the occlusive barrier lasts long enough and if the barrier membrane is not exposed to the oral cavity, optimal conditions exist for stem cells and osteoprogenitor cells to differentiate into osteoblasts, which deposit the bone matrix. In other words, the barrier membrane creates a secluded space that allows bone to use its great, natural healing capacity in an undisturbed and protected manner. Both resorbable and nonresorbable membranes are available on the market [7].

The ideal bioresorbable membrane for GBR has the following characteristics: biocompatibility, produces no inflammatory reaction, is totally resorbed, degraded and eliminated, easy to handle, cut, contour and adapt, maintains the desired shape and configuration, easily secured in place, reliably excludes non-osseous tissues from the defect, resistant to bacterial attachment and colonization, has a predictable resorption time that is compatible with bone formation $[8,9]$.

Two materials are mainly used to manufacture resorbable membranes: synthetic aliphatic polyester and collagen derived from different animal sources. Most of the commercially available collagen membranes have been developed from type I collagen, a predominant component of the periodontal connective tissue, or from a combination of type I and type III collagen. Collagen sources in the barriers vary and include bovine tendons, bovine dermis, calf skin, or porcine dermis. In the literature, several advantages of collagen materials have been mentioned, including hemostasis, chemotaxis for periodontal ligament fibroblasts and gingival fibroblasts, weak immunogenicity, easy manipulation, a direct effect on bone formation, and an 
ability to augment tissue thickness. Collagen material appears to be an ideal choice for the bioresorbable GBR barrier [10-12].

Collagen membranes have also been reported to have unfavorable mechanical properties and to function inadequately as a barrier because of their fast biodegradation through the enzymatic activities of macrophages and polymorphonuclear leukocytes. To prolong the barrier function of collagen membranes, several cross-linking technologies, such as ultraviolet radiation, glutaraldehyde, diphenylphosphoryl-azide, and hexamethylene disocyanate have been used. Cross-linking increases the structural stability and slows down the process of degradation [13].

The aim of this paper was to examine and compare the impact of resorbable human demineralized membrane (RHDM) and resorbable bovine demineralized membrane (RBDM), both produced at the Department of Implantology of the Military Medical Academy, on the ossification of bone defects in an experimental study on dogs.

\section{MATERIALS AND METHODS}

This experimental study was performed at the Department of Implantology (Military Medical Academy - MMA), and the Institute for Medical Research (MMA). The experiment had three phases and involved 6 adult German Shepherd female dogs, with medium weight of $24.1 \mathrm{~kg}$ and average age 5.1 years, abiding by all the ethical principles, as stipulated in the relevant MMA regulations.

\section{The first phase of the experiment}

Propionyl promazine $1 \%$ (Combelen ${ }^{\circledR}$, intravenous, $0.3 \mathrm{ml} / \mathrm{kg} \mathrm{BW}$ ) and atropine (subcutaneous, $0.03 \mathrm{ml} / \mathrm{kg} \mathrm{BW}$ ) were used as premedication. Ketamine chloride $5 \%$ (intramuscular, $0.3 \mathrm{ml} / \mathrm{kg} \mathrm{BW}$ ) was injected 15 minutes after the premedication.

During this short intravenous anesthesia, extractions of the second, third, and fourth premolar on the left side of the mandible were performed. Extraction wounds were closed using individual surgical sutures (Dexon 3,0, Davis \& Gack).

Postoperative antibiotic therapy consisted of intravenous administration of 1.600.000 IU of crystalline penicillin for two days. The health status of the experimental animals was controlled daily, while the dogs were kept in separate boxes and fed soft food. The first phase of the experiment ended eight weeks after extraction.

\section{The second phase of the experiment}

At the Department of Implantology of Military Medical Academy (MMA), a resorbable human demineralized membrane (RHDM) and resorbable bovine demineralized membrane (RBDM) have been developed (patent number 760/002). RHDM and RBDM are implantation materials of human and bovine origin, the structures of which are a barrier to connective tissue ingrowth from the mucoperiostal flap, and organic 
composition which stimulates osteogenesis of the host bone. They are produced with a combination of physical and chemical methods (demineralization of cortical bone with successive removal of lipoproteins) from the calvarial region of human cadavers and bovine sources. Quantitative analyses (Micro-Qeldel, Hydroxyprolin test) and qualitative analyses (collagenase tests, electrophoresis) have shown that the membranes consist of organic components made of collagen type I. The membranes are sterilized using gamma radiation at the end of the production process, what makes them cross-linked.

Eight weeks after teeth extraction the defects were created. Crystalline penicillin (1.600.000 IU) was administered as prophylaxis. After a supracrestal incision and vertical relaxations $2-3 \mathrm{~mm}$ away from the adjacent teeth, a full thickness flap was elevated. On the left side of the lower alveolar ridge occlusally, bone defects were prepared, using a bone trepan (diameter $4 \mathrm{~mm}$ ), with copious irrigation with sterile saline solution. Three bone defects were prepared. The first defect was covered with a resorbable human demineralized membrane $200 \mu \mathrm{m}$ thick, the second with a resorbable bovine demineralized membrane $200 \mu \mathrm{m}$ thick, and the third was left uncovered (control defect).

Each membrane was shaped to cover the defect completely, extending at least 2-3 mm beyond the defect edges. The wounds were closed using individual surgical sutures.

At the end of each of the surgical procedures, and in two more instances afterwards, an analgesic was administered to reduce postoperative pain. The dogs were fed a soft diet until the end of the experiment.

\section{The third phase of the experiment}

Sacrificing of experimental animals (euthanasia) was done 2, 4, and 6 months after surgical intervention (two dogs in each instance). Euthanasia was accomplished using the barbiturate thiopental sodium solution (intravenously, $1 \mathrm{~g}$ per $30 \mathrm{~kg} \mathrm{BW}$ ). The samples were prepared for histological analysis. Each sample was cut with a special saw to smaller sections containing the jaw bone defect with the appropriate membrane. The tissue samples were placed in a decalcination solution, and then embedded in paraffin, cut with a microtome in several 5-7 $\mu \mathrm{m}$ thick sections and stained with HE, van Gieson, van Kossa, Goldner trichrome, Masson trichrome, PAS, PAS diastase, and toluidine blue.

The preparations were analyzed by light microscopy (Leitz microscope).

The following characteristics were analyzed pathohistologically: preservation of compact bone tissue, border between soft tissue elements and newly formed bone trabeculae, presence of osteocytes in the lacunas, osteoblastic reaction, presence of young blood vessels and fibrocytes, maturity of newly formed connective tissue, and degree of defect-filling with new bone tissue. 
The Kruscal-Wallis and the Wilcoxon rank-sum tests (Wa test) were used for the purpose of statistical analysis of pathohistologic results.

\section{RESULTS}

The following characteristics were estimated by description of histological samples according to consecutive criterions in Table 1 and Figures 1 and 2.

Table 1. The criteria for estimation of histological characteristics

\begin{tabular}{|c|c|c|c|}
\hline \multirow{2}{*}{ Histological property } & \multicolumn{3}{|c|}{ Mark } \\
\hline & „0” & „1" & „2” \\
\hline Compactness of bone tissue & Not preservrd & $\begin{array}{l}\text { Partially } \\
\text { preserved }\end{array}$ & Preserved \\
\hline $\begin{array}{l}\text { Borderline between soft tissue elements and } \\
\text { newly formed bone }\end{array}$ & Unclear & Partially clear & Clear \\
\hline Presence of osteocytes in lacunas & Empty & $\begin{array}{l}\text { Partially } \\
\text { complete }\end{array}$ & Complete \\
\hline Osteblastic reaction & Absent & Moderate & Marked \\
\hline $\begin{array}{l}\text { Presence of young blood vessels, fibroblasts } \\
\text { and fibrocytes }\end{array}$ & Not marked & Partially marked & Marked \\
\hline Maturity of newly formed connective tissue & Young, immature & Partially mature & Mature \\
\hline Defect filling with newly formed bone tissue & $\begin{array}{l}\text { Defect filling } \\
\text { about a } 1 / 3\end{array}$ & $\begin{array}{l}\text { Defect filling } \\
\text { less than } 2 / 3\end{array}$ & $\begin{array}{l}\text { Defect filling } \\
\text { more than } 2 / 3\end{array}$ \\
\hline
\end{tabular}

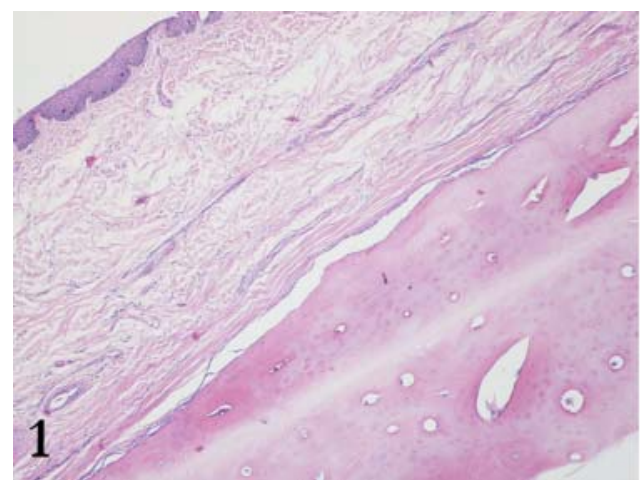

Figure 1. Clear border between soft tissue of the gingiva and bone tissue (RHDM $200 \mu \mathrm{m})$

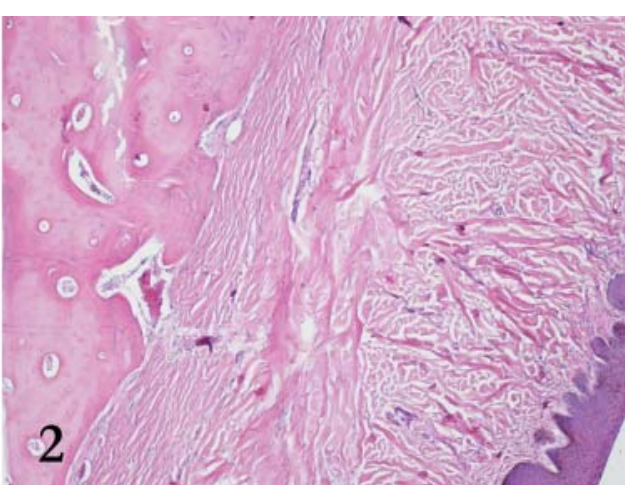

Figure 2. The border between soft tissue of the gingiva and bone tissue is partially clear, and partially the soft tissue ingrowth can be seen $(\mathrm{RBDM} 200 \mu \mathrm{m})$

The analyzed characteristics are presented in Tables 2, 3 and 4. 
Table 2. Comparative pathohistological findings 2 months after surgical intervention

\begin{tabular}{|c|c|c|c|c|c|c|}
\hline \multirow{3}{*}{$\begin{array}{l}\text { Property } \\
\text { Compactness of bone tissue }\end{array}$} & \multicolumn{6}{|c|}{ Method - findings (mark) } \\
\hline & \multicolumn{2}{|c|}{ RHDM (I) } & \multicolumn{2}{|r|}{ RBDM (II) } & \multicolumn{2}{|c|}{ Control defect } \\
\hline & 2 & Preserved & 2 & Preserved & 0 & Not preserved \\
\hline $\begin{array}{l}\text { Borderline between soft tissue } \\
\text { elements and newly formed bone }\end{array}$ & 2 & $\begin{array}{l}\text { Clear } \\
\text { (no ingrowth) }\end{array}$ & 1 & $\begin{array}{l}\text { Spots of } \\
\text { proliferation } \\
\text { of soft tissue } \\
\text { elements }\end{array}$ & 0 & $\begin{array}{l}\text { Unclear, with } \\
\text { soft tissue } \\
\text { ingrowth }\end{array}$ \\
\hline Presence of osteocytes in lacunas & 2 & Complete & 2 & Complete & 0 & Empty lacunas \\
\hline Osteblastic reaction & 2 & Marked & 1 & Moderate & 0 & Absent \\
\hline $\begin{array}{l}\text { Presence of young blood vessels, } \\
\text { fibroblasts and fibrocytes }\end{array}$ & 2 & Marked & 2 & Marked & 2 & Marked \\
\hline $\begin{array}{l}\text { Maturity of newly formed } \\
\text { connective tissue }\end{array}$ & 1 & $\begin{array}{l}\text { Partially } \\
\text { mature }\end{array}$ & 0 & Immature & 0 & Immature \\
\hline $\begin{array}{l}\text { Defect filling with newly formed } \\
\text { bone tissue }\end{array}$ & 1 & About a third & 0 & $\begin{array}{l}\text { Less than a } \\
\text { third of defect } \\
\text { size }\end{array}$ & 0 & $\begin{array}{l}\text { Less than a } \\
\text { third of defect } \\
\text { size }\end{array}$ \\
\hline Amount: & 12 & & 8 & & 2 & \\
\hline
\end{tabular}

Table 3. Comparative pathohistological findings 4 months after surgical intervention

\begin{tabular}{|c|c|c|c|c|c|c|}
\hline \multirow{3}{*}{$\begin{array}{l}\text { Property } \\
\text { Compactness of bone tissue }\end{array}$} & \multicolumn{6}{|c|}{ Method - findings (mark) } \\
\hline & \multicolumn{2}{|r|}{ RHDM (I) } & \multicolumn{2}{|c|}{ RBDM (II) } & \multicolumn{2}{|c|}{ Control defect } \\
\hline & 2 & Preserved & 2 & Preserved & 0 & Not preserved \\
\hline $\begin{array}{l}\text { Borderline between soft tissue } \\
\text { elements and newly formed bone }\end{array}$ & 2 & $\begin{array}{l}\text { Clear } \\
\text { (no ingrowth) }\end{array}$ & 2 & $\begin{array}{l}\text { Clear } \\
\text { (no ingrowth) }\end{array}$ & 0 & $\begin{array}{l}\text { Unclear, with } \\
\text { soft tissue } \\
\text { ingrowth }\end{array}$ \\
\hline Presence of osteocytes in lacunas & 2 & Complete & 2 & Complete & 0 & Empty lacunas \\
\hline Osteblastic reaction & 2 & Marked & 2 & Marked & 1 & Moderate \\
\hline $\begin{array}{l}\text { Presence of young blood vessels, } \\
\text { fibroblasts and fibrocytes }\end{array}$ & 2 & Marked & 2 & Marked & 2 & Marked \\
\hline $\begin{array}{l}\text { Maturity of newly formed } \\
\text { connective tissue }\end{array}$ & 1 & $\begin{array}{l}\text { Immature, } \\
\text { spotty } \\
\text { transformation } \\
\text { to mature } \\
\text { tissue }\end{array}$ & 0 & Immature & 0 & Immature \\
\hline $\begin{array}{l}\text { Defect filling with newly formed } \\
\text { bone tissue }\end{array}$ & 2 & $\begin{array}{l}\text { More than a } \\
\text { two third of } \\
\text { defect size }\end{array}$ & 1 & $\begin{array}{l}\text { About two } \\
\text { third of } \\
\text { defect size }\end{array}$ & 0 & $\begin{array}{l}\text { Less than a } \\
\text { two third of } \\
\text { defect size }\end{array}$ \\
\hline Amount: & 13 & & 11 & & 3 & \\
\hline
\end{tabular}


Table 4. Comparative pathohistological findings 6 months after surgical intervention

\begin{tabular}{|c|c|c|c|c|c|c|}
\hline \multirow{3}{*}{$\begin{array}{l}\text { Property } \\
\text { Compactness of bone tissue }\end{array}$} & \multicolumn{6}{|c|}{ Method - findings (mark) } \\
\hline & \multicolumn{2}{|c|}{ RHDM (I) } & \multicolumn{2}{|r|}{ RBDM (II) } & \multicolumn{2}{|c|}{ Control defect } \\
\hline & 2 & Preserved & 2 & Preserved & 0 & Not preserved \\
\hline $\begin{array}{l}\text { Borderline between soft tissue } \\
\text { elements and newly formed bone }\end{array}$ & 2 & $\begin{array}{l}\text { Clear } \\
\text { (no ingrowth) }\end{array}$ & 2 & $\begin{array}{l}\text { Clear } \\
\text { (no ingrowth) }\end{array}$ & 1 & $\begin{array}{l}\text { Unclear, with } \\
\text { soft tissue } \\
\text { ingrowth }\end{array}$ \\
\hline Presence of osteocytes in lacunas & 2 & Complete & 2 & Complete & 2 & Complete \\
\hline Osteblastic reaction & 2 & Marked & 2 & Marked & 2 & Marked \\
\hline $\begin{array}{l}\text { Presence of young blood vessels, } \\
\text { fibroblasts and fibrocytes }\end{array}$ & 2 & Marked & 2 & Marked & 2 & Marked \\
\hline $\begin{array}{l}\text { Maturity of newly formed } \\
\text { connective tissue }\end{array}$ & 2 & $\begin{array}{l}\text { Multiplied, } \\
\text { mostly mature } \\
\text { connective } \\
\text { tissue }\end{array}$ & 1 & $\begin{array}{l}\text { Immature, } \\
\text { spotty } \\
\text { transformation } \\
\text { to mature } \\
\text { tissue }\end{array}$ & 0 & Immature \\
\hline $\begin{array}{l}\text { Defect filling with newly formed } \\
\text { bone tissue }\end{array}$ & 2 & $\begin{array}{l}\text { Defect filled } \\
\text { for the most } \\
\text { part filled } \\
\text { with newly } \\
\text { formed bone } \\
\text { tissue }\end{array}$ & 1 & $\begin{array}{l}\text { About two } \\
\text { third of defect } \\
\text { size }\end{array}$ & 0 & $\begin{array}{l}\text { Less than a two } \\
\text { third of defect } \\
\text { size }\end{array}$ \\
\hline Amount: & 14 & & 12 & & 7 & \\
\hline
\end{tabular}

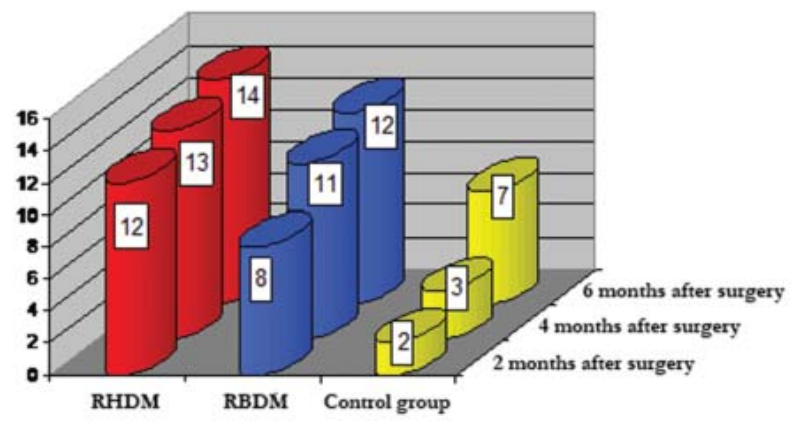

Chart 1. Comparative chart of sums at 2, 4 and 6 months after surgery

The methods of guided tissue regeneration:

I - Resorbable human demineralized membrane $200 \mu \mathrm{m}$ thick (RHDM);

II - Resorbable bovine demineralized membrane $200 \mu \mathrm{m}$ thick (RBDM); and

III - Defects without a membrane (controls). 
Table 5. Comparative statistics of histological characteristics 2 months after surgery

\begin{tabular}{|c|c|c|c|}
\hline \multirow{2}{*}{$\begin{array}{c}\text { Kruskal-Wallis } \\
\text { H0: M1=M2=M3 } \\
\text { H1: M1\#M2\#M3 } \\
\text { significant level }(\alpha=0,2)\end{array}$} & \multicolumn{3}{|c|}{$\begin{array}{l}\text { Compactness of bone tissue } \\
\text { Wilcoxon Wa; significant level }(\alpha=0,167) \text {; significant interval }(7,3)\end{array}$} \\
\hline & $\begin{array}{c}\text { I - II } \\
\text { H0: M1=M2, } \\
\text { H1: M1>M2 }\end{array}$ & $\begin{array}{c}\text { I - III } \\
\text { H0: M1=M3, } \\
\text { H1: M1>M3 }\end{array}$ & $\begin{array}{c}\text { II }- \text { III } \\
\text { H0: M2=M3, } \\
\text { H1: M2>M3 }\end{array}$ \\
\hline $\mathrm{H}=3,43 / \mathrm{Hv}_{\mathrm{v}}=2, \alpha<3,71$ & $\mathrm{Wa}=5$ & $\mathrm{Wa}=7$ & $\mathrm{Wa}=7$ \\
\hline- & - & + & + \\
\hline & \multicolumn{3}{|c|}{ Borderline between soft tissue elements and newly formed bone } \\
\hline $\mathrm{H}=4,57 / \mathrm{Hv}_{\mathrm{v}}=2, \alpha<3,71$ & $\mathrm{Wa}=7$ & $\mathrm{Wa}=7$ & $\mathrm{Wa}=7$ \\
\hline \multirow[t]{2}{*}{+} & + & + & + \\
\hline & \multicolumn{3}{|c|}{ Presence of osteocytes in lacunas } \\
\hline $\mathrm{H}=3,43 / \mathrm{Hv}_{\mathrm{v}}=2, \alpha<3,71$ & $\mathrm{Wa}=5$ & $\mathrm{Wa}=7$ & $\mathrm{Wa}=7$ \\
\hline \multirow[t]{2}{*}{-} & - & + & + \\
\hline & \multicolumn{3}{|c|}{ Osteblastic reaction } \\
\hline $\mathrm{H}=4,57 / \mathrm{Hv}_{\mathrm{v}}=2, \alpha<3,71$ & $\mathrm{Wa}=7$ & $\mathrm{Wa}=7$ & $\mathrm{Wa}=7$ \\
\hline \multirow[t]{2}{*}{+} & + & + & + \\
\hline & \multicolumn{3}{|c|}{ Presence of young blood vessels, fibroblasts and fibrocytes } \\
\hline $\mathrm{H}=0,00 / \mathrm{Hv}=2, \alpha<3,71$ & $\mathrm{Wa}=5$ & $\mathrm{Wa}=5$ & $\mathrm{Wa}=5$ \\
\hline \multirow[t]{2}{*}{-} & - & - & - \\
\hline & \multicolumn{3}{|c|}{ Maturity of newly formed connective tissue } \\
\hline $\mathrm{H}=3,43 / \mathrm{Hv}_{\mathrm{v}}=2, \alpha<3,71$ & $\mathrm{Wa}=7$ & $\mathrm{Wa}=7$ & $\mathrm{Wa}=5$ \\
\hline \multirow[t]{2}{*}{-} & + & + & - \\
\hline & \multicolumn{3}{|c|}{ Defect filling with newly formed bone tissue } \\
\hline $\mathrm{H}=3,43 / \mathrm{Hv}=2, \alpha<3,71$ & $\mathrm{Wa}=7$ & $\mathrm{Wa}=7$ & $\mathrm{Wa}=5$ \\
\hline- & + & + & - \\
\hline
\end{tabular}

+ presence of a statistically significant difference; - absence of a statistically significant difference

The calculated statistic values of the Wa test, showed that the RHDM method achieved better results in comparison with the RBDM method in the period of 2 months after surgery for 4 analyzed characteristics or in $57.14 \%$ cases. For the 3 remaining characteristics the effects were the same.

In comparison with the control group, the RHDM method was significantly better in 6 analyzed characteristics or in $85.71 \%$ cases.

In comparison with the control group, RBDM method achieved better effects in 4 analyzed characteristics or in $57.14 \%$ cases.

The calculated statistical values of the Wa test, showed that the RHDM method achieved better results in comparison with the RBDM method in the period of 4 months after surgery in 2 analyzed characteristics or in $28.57 \%$ cases, which presents a decrease with regard to the period of 2 months after surgery. In 5 rest characteristics the effects were the same. 
Table 6. Comparative statistics of histological characteristics 4 months after surgery

\begin{tabular}{|c|c|c|c|}
\hline \multirow{2}{*}{$\begin{array}{c}\text { Kruskal-Wallis } \\
\text { H0: M1=M2=M3 } \\
\text { H1: M1\#M2\#M3 } \\
\text { significant level }(\alpha=0,2)\end{array}$} & \multicolumn{3}{|c|}{$\begin{array}{l}\text { Compactness of bone tissue } \\
\text { Wilcoxon Wa; significant level }(\alpha=0,167) \text {; significant interval }(7,3)\end{array}$} \\
\hline & $\begin{array}{c}\text { I - II } \\
\text { H0: M1=M2, } \\
\text { H1: M1>M2 }\end{array}$ & $\begin{array}{c}\text { I - III } \\
\text { H0: M1=M3, } \\
\text { H1: M1>M3 }\end{array}$ & $\begin{array}{c}\text { II - III } \\
\text { H0: M2=M3, } \\
\text { H1: M2>M3 }\end{array}$ \\
\hline $\mathrm{H}=3,43 / \mathrm{Hv}=2, \alpha<3,71$ & $\mathrm{Wa}=5$ & $\mathrm{Wa}=7$ & $\mathrm{Wa}=7$ \\
\hline- & - & + & + \\
\hline & \multicolumn{3}{|c|}{ Borderline between soft tissue elements and newly formed bone } \\
\hline $\mathrm{H}=3,43 / \mathrm{Hv}=2, \alpha<3,71$ & $\mathrm{Wa}=5$ & $\mathrm{Wa}=7$ & $\mathrm{Wa}=7$ \\
\hline \multirow{2}{*}{ ( } & - & + & + \\
\hline & \multicolumn{3}{|c|}{ Presence of osteocytes in lacunas } \\
\hline $\mathrm{H}=3,43 / \mathrm{Hv}=2, \alpha<3,71$ & $\mathrm{Wa}=5$ & $\mathrm{Wa}=7$ & $\mathrm{Wa}=7$ \\
\hline \multirow[t]{2}{*}{-} & - & + & + \\
\hline & \multicolumn{3}{|c|}{ Osteblastic reaction } \\
\hline $\mathrm{H}=3,43 / \mathrm{Hv}=2, \alpha<3,71$ & $\mathrm{Wa}=5$ & $\mathrm{Wa}=7$ & $\mathrm{Wa}=7$ \\
\hline \multirow[t]{2}{*}{+} & - & + & + \\
\hline & \multicolumn{3}{|c|}{ Presence of young blood vessels, fibroblasts and fibrocytes } \\
\hline $\mathrm{H}=0,00 / \mathrm{Hv}=2, \alpha<3,71$ & $\mathrm{Wa}=5$ & $\mathrm{Wa}=5$ & $\mathrm{Wa}=5$ \\
\hline \multirow[t]{2}{*}{-} & - & - & - \\
\hline & \multicolumn{3}{|c|}{ Maturity of newly formed connective tissue } \\
\hline $\mathrm{H}=3,43 / \mathrm{Hv}=2, \alpha<3,71$ & $\mathrm{Wa}=7$ & $\mathrm{Wa}=7$ & $\mathrm{Wa}=5$ \\
\hline \multirow[t]{2}{*}{-} & + & + & - \\
\hline & \multicolumn{3}{|c|}{ Defect filling with newly formed bone tissue } \\
\hline $\mathrm{H}=4,57 / \mathrm{Hv}=2, \alpha<3,71$ & $\mathrm{Wa}=7$ & $\mathrm{Wa}=7$ & $\mathrm{Wa}=5$ \\
\hline+ & + & + & + \\
\hline
\end{tabular}

+ presence of a statistically significant difference; - absence of a statistically significant difference

In comparison with the control group, the RHDM method was significantly better in 6 analyzed characteristics or in $85.17 \%$ cases.

In comparison with the control group, RBDM method achieved better effects in 5 analyzed characteristics or in $71.42 \%$ cases, which presents an improvement with regard to the period of 2 months after surgery.

The calculated statistical values of the Wa test, showed that the RHDM method achieved better results in comparison with the RBDM method in the period of 6 months after surgery in 3 analyzed characteristics or in $57.14 \%$ cases, which presents a moderate increase with regard to the period of 4 months after surgery. In remaining 4 characteristics the effects were the same.

In comparison with the control group, the RHDM method was significantly better in 4 analyzed characteristics or in $57.14 \%$ cases. 
Table 7. Comparative statistics of histological characteristics 6 months after surgery

\begin{tabular}{|c|c|c|c|}
\hline \multirow{2}{*}{$\begin{array}{c}\text { Kruskal-Wallis } \\
\text { H0: M1=M2=M3 } \\
\text { H1: M1\#M2\#M3 } \\
\text { significant level }(\alpha=0,2)\end{array}$} & \multicolumn{3}{|c|}{$\begin{array}{l}\text { Compactness of bone tissue } \\
\text { Wilcoxon Wa; significant level }(\alpha=0,167) \text {; significant interval }(7,3)\end{array}$} \\
\hline & $\begin{array}{c}\mathrm{I}-\mathrm{II} \\
\mathrm{H} 0: \mathrm{M} 1=\mathrm{M} 2, \\
\mathrm{H} 1: \mathrm{M} 1>\mathrm{M} 2\end{array}$ & $\begin{array}{c}\text { I - III } \\
\text { H0: M1=M3, } \\
\text { H1: M1>M3 }\end{array}$ & $\begin{array}{c}\text { II - III } \\
\text { H0: M2=M3, } \\
\text { H1: M2>M3 }\end{array}$ \\
\hline $\mathrm{H}=4,57 / \mathrm{Hv}=2, \alpha<3,71$ & $\mathrm{Wa}=5$ & $\mathrm{Wa}=7$ & $\mathrm{Wa}=7$ \\
\hline+ & + & + & + \\
\hline & \multicolumn{3}{|c|}{ Borderline between soft tissue elements and newly formed bone } \\
\hline $\mathrm{H}=3,43 / \mathrm{Hv}=2, \alpha<3,71$ & $\mathrm{Wa}=5$ & $\mathrm{Wa}=7$ & $\mathrm{Wa}=7$ \\
\hline \multirow[t]{2}{*}{-} & - & + & + \\
\hline & \multicolumn{3}{|c|}{ Presence of osteocytes in lacunas } \\
\hline $\mathrm{H}=0,00 / \mathrm{Hv}=2, \alpha<3,71$ & $\mathrm{Wa}=5$ & $\mathrm{Wa}=5$ & $\mathrm{Wa}=5$ \\
\hline \multirow[t]{2}{*}{-} & - & - & - \\
\hline & \multicolumn{3}{|c|}{ Osteblastic reaction } \\
\hline $\mathrm{H}=0,00 / \mathrm{Hv}=2, \alpha<3,71$ & $\mathrm{Wa}=5$ & $\mathrm{Wa}=5$ & $\mathrm{Wa}=5$ \\
\hline \multirow[t]{2}{*}{-} & - & - & - \\
\hline & \multicolumn{3}{|c|}{ Presence of young blood vessels, fibroblasts and fibrocytes } \\
\hline $\mathrm{H}=0,00 / \mathrm{Hv}=2, \alpha<3,71$ & $\mathrm{Wa}=5$ & $\mathrm{Wa}=5$ & $\mathrm{Wa}=5$ \\
\hline \multirow[t]{2}{*}{-} & - & - & - \\
\hline & \multicolumn{3}{|c|}{ Maturity of newly formed connective tissue } \\
\hline $\mathrm{H}=4,57 / \mathrm{Hv}_{\mathrm{v}}=2, \alpha<3,71$ & $\mathrm{Wa}=7$ & $\mathrm{Wa}=7$ & $\mathrm{Wa}=7$ \\
\hline \multirow[t]{2}{*}{-} & + & + & + \\
\hline & \multicolumn{3}{|c|}{ Defect filling with newly formed bone tissue } \\
\hline$H=4,57 / H_{v}=2, \alpha<3,71$ & $\mathrm{Wa}=7$ & $\mathrm{Wa}=7$ & $\mathrm{Wa}=5$ \\
\hline+ & + & + & + \\
\hline
\end{tabular}

+ presence of a statistically significant difference; - absence of a statistically significant difference

In comparison with the control group, RBDM method achieved better effects in $57.14 \%$ cases.

\section{DISCUSSION}

In the last two decades, numerous experimental and clinical studies have described and examined a large number of barrier membranes, their properties, and roles in guided bone regeneration [11-18].

Schenek et al. [19] in their study on mandibular defects in dogs described microscopically three categories of bone tissue encountered in the process of regeneration:

- Woven bone - characterized by netlike distribution of bone trabeculae, with plenty of spherical osteocytes and rich blood supply to the connective tissue between bone trabeculae; 
- Fibrillar bone - consists of parallel collagen fibers, with less osteocytes. Growing bone forms a primary osteon, positioned in the periosteal and endoosteal apposition;

- Lamellar bone - a mature bone with lamellar structure.

They examined and analyzed the pathohistological significance of barrier membranes. Based on these findings, the authors concluded that bone regeneration was incomplete after 4 months, and suggested longer periods of healing.

In a pilot study, Colangelo et al. created "through and trough" defects on the lateral aspect of rabbit mandibles and then treated these defects with either a type I highly cross-linked membrane or no-treatment (control). The histological evaluation at 30 days demonstrated a nearly complete continuous layer of lamellar bone with osteoblastic activity in the collagen membrane-treated group compared to only fibrous connective tissue in the control group [20].

In another study, Zitzmann at al. compared a resorbable collagen membrane (Biogide $\left.{ }^{\circledR}\right)$ to the conventional e-PTFE material (Gore-Tex ${ }^{\circledR}$ ) for guided bone regeneration in situations involving exposed implant surfaces. Over a 2 -year period, 25 split-mouth patients were treated randomly: one defect site was treated with Bio-gide $\AA$ and the other defect site with Gore-Tex®; all 84 defects were filled with Bio-oss ${ }^{\circledR}$ and covered with the respective membrane. Changes in defect surface for both types of membranes were statistically significant. The mean average percentage of bone fill was $92 \%$ for Bio-gide $\AA$ and $78 \%$ for Gore-tex ${ }^{\circledR}$ sites. In the latter group, 44\% wound dehiscence and/or premature membrane removal occurred. The resorbable membrane, Biogide ${ }^{\circledR}$, in combination with a bone substitute, can be a useful alternative to wellestablished e-PTFE membranes [21].

In a report on the bio-degradation of various collagen membranes implanted in rats, Rothamel et al. reported that non-cross linked porcine derived types I and III collagen (Bio-gide ${ }^{\circledR}$ ) exhibited a perfect tissue integration and thereby rapid vascularisation, resulting in a nearly complete biodegradation 4 weeks following implantation without observable foreign body reactions. The cross-linked bovine collagen membrane (Ossix $\left.{ }^{\circledR} T M\right)$ underwent the least amount of degradation after six months, maintaining greater thickness and occlusive function compared to porcine collagen (Bio-gide ${ }^{\circledR}$ ), however it exhibited decreased tissue integration and vascularisation and was associated with foreign body reaction. Three other commercially available bovine collagen membranes (BioMend $\AA$, BioMendExtend $\AA$, TutuDent $\AA)$, and three protype collagen membranes VN (chemical cross-linked porcine type I and type III collagens) were included in the study. They concluded that the higher the degree of cross-linking, the longer the resorption rate [15].

Another study was aimed to clinically and histomorphometrically compare two collagen membranes, Bio-gide ${ }^{\circledR}$ and BioMendExtend TM, for the treatment of implant dehiscence defects in eight mongrel dogs. Implant dehiscence defects were surgically 
created in edentuolous ridges, followed by the placement of three endosseus implants bilaterally in the mandible. Each implant dehiscence defect was randomly assigned to one of three treatment groups: 1- control (no membrane), 2- dermis collagen barrier (Bio-gide $(\mathrm{R})$ and 3- bovine tendon collagen barrier (BioMendExtend TM). Dogs were sacrificed at 4 and 16 weeks (four dogs each) after treatment. The results of the study revealed no significant differences among groups for any parameter at 4 weeks. However, at 16 weeks more linear bone fill (LF), bone to implant contact (BIC) and new bone fill were noted in the membrane treated groups than controls [22].

Pathohistological findings in our study are almost identical to the findings of Schenek et al. [19], but their study was less informative as to the course and appearance of bone regeneration in mandibular bone defects.

In our study, pathohistological analysis of the defects with human and bovine membranes two months after surgery, demonstrated a clear-cut borderline between soft tissue elements and compact bone exclusively in the defects covered with the human membrane. Compared to others, this was also the defect which was best filled with immature connective tissue, rich in fibroblasts, and with a numerous newly formed, thin walled, and dilated blood vessels. In the young connective tissue, newly formed shorter and thinner fibrillar bone trabeculae could be observed, in a netlike distribution pattern and with osteoblastic reaction. As for the control defects, the borderline between bone and connective tissue was poorly defined along the whole of its length. Connective tissue elements penetrated deeply into the bone tissue, so that the remnants of bone trabeculae were seen in the connective tissue, having an almost „embedded“ appearance. The region of preserved bone tissue beneath the soft tissue was very narrow as a consequence of proliferation of soft tissue into the bone and its subsequent destruction. In animals sacrificed 2 months after surgery, we could see mostly the remnants of bone trabeculae, with empty lacunas and without osteocytes. Between the fragments of bone trabeculae, the growth of immature connective tissue could be observed, with rich blood supply and with numerous fibroblasts and fibrocytes.

Four months after surgery, pathohistologic analysis revealed that the borderline between the soft tissue and compact bone in both membrane-covered defects was clear, and that there was no proliferation of connective tissue elements. Immature connective tissue was growing mature, and a considerable amount of trabecular bone with a pronounced osteoblastic reaction could be seen. After four months, the defect covered with human membrane was the fullest one (although just slightly more than half of its size). As for the control defects, the borderline between bone and connective tissue was poorly defined along the whole of its length. Four months after the bone defect was made, clear connective tissue proliferation could be seen, rich in fibroblasts and young blood vessels, as well as a considerable number of new bone trabeculae with signs of osteoblastic reaction. The defect was for the most part filled with immature, amply vascularized connective tissue. 
Six months after surgery, pathohistological analysis demonstrated that the borderline between bone and soft tissue was clear and without proliferation and ingrowth of soft tissue elements into the bone tissue. In the central area, beneath the compact bone, enlarged, mostly mature tissue could be seen, rich in fibroblasts and fibrocytes, and with numerous young, thin-walled, dilated blood vessels. In the connective tissue, there were thicker and thinner bone trabeculae, with osteocytes in the lacunas, and with a marked osteoblastic reaction. Both membrane covered defects were for the most part filled with newly formed bone tissue. The defect covered with the human membrane was almost completely filled.

In control defects, in the sections taken 6 months after sacrificing, in the newly formed, well vascularized connective tissue, a considerable number of thin, shorter or longer fibrillar bone trabeculae were seen, with a marked osteoblastic reaction and in a netlike distribution pattern. Soft tissue ingrowth into the bone was obvious. Bone defects were filled to a higher degree compared to the defects seen after 4 months, although not complete as yet; and after 6 months, the defects were filled for more than half of their size, but significantly less compared to the ones covered with membranes.

Pathohistological findings in our experiment demonstrated that the use of membranes as an interface between soft tissue elements and bone was able to prevent the ingrowth of soft tissue into the new bone, i.e. in the space between the bone and membrane, contributing therefore to a better filling of mandibular defects with newly formed bone.

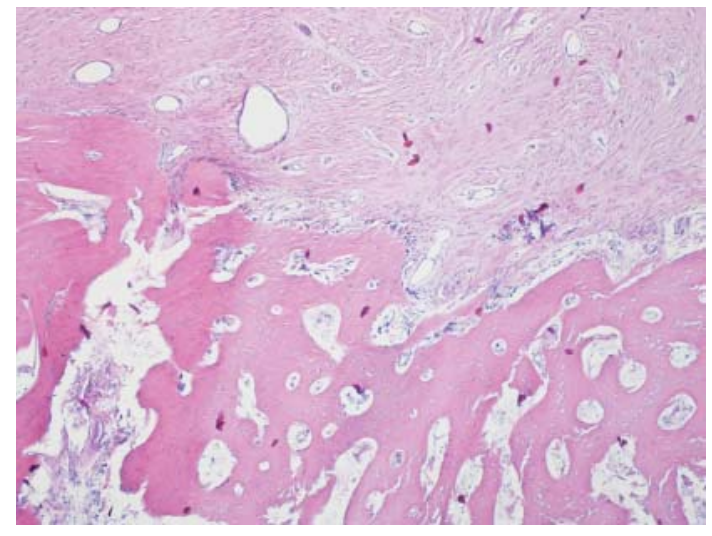

Figure 3. The border between the soft tissue of the gingiva and bone tissue is unclear. The ingrowth of the soft tissue deeply in bone can be seen

\section{CONCLUSION}

The use of a human membrane, as shown in our study, produced better results than the use of a bovine membrane, since it showed better results in four properties two months after surgery, in two properties four months after surgery and in three properties 
six months after surgery. The human membrane contributed to the maturation of connective tissue and more rapid defect filling with newly formed bone.

\section{REFERENCES}

1. Urist MR. Bone formation by autoinduction. Science 1965, 150:893-899.

2. Reddi AH, Weintroub S, Muthukumaran N. Biologic principles of bone induction. Orthopedic Clinics of North America. 1987, 18: 207-212.

3. Block MS, Baughman DG. 2005 Reconstruction of severe anterior maxillary defects using distraction osteogenesis, bone grafts and implants. J Oral Maxillofac Surg 2005, 63:291297.

4. Oda T, Suzuki H, Yokota M, Ueda M. Horizontal alveolar distraction of the narrow maxillary ridge for implant placement. J. Oral Maxillofac Surg 2004, 62: 1530-1534.

5. Buser D, Dula K, Hess D, Hirt HP, Belser UC. Localized ridge augmentation with autografts and barrier membranes. Periodontology 1999, 19: 151-163.

6. Von Arx T, Buser D. Horizontal ridge augmentation using autogenous block grafts and the guided bone regeneration technique with collagen membranes: a clinical study with 42 patients. Clinical Oral Implants Research 2006, 17: 359-366.

7. Hammerle CH, Jung RE, Feloutzis A. Asystematic review of the survival of implants in bone sites augmented with barrier membranes (guided bone regeneration) in partially edentulous patients. Journal of Clinical Periodontology2002, 29 (Suppl 3): 226-231.

8. Gottlow J. Guided tissue regeneration using bioresorbable and non-resorbable devices: Initial healing and long-term results. Journal of Periodontology 1993, 64: 1157-1165.

9. Hardwick R, Scantlebury TV, Sanches R, Whitley N, Ambruster J. Membrane design criteria for guided bone regeneration of the alveolar ridge In: Buser D, Dahlin C, Schenk RK. Guided bone regeneration in Implant Dentistry 1994, Chicago, Berlin, Quintessence: 101-136.

10. Pitaru S, Tal H, Soldinger M, Grosskopf A, Noff M.Partial regeneraton of collagen tissues using collagen barriers: initial observation in canine. Journal of Periodontology 1988, 59: 380-386.

11. Tal H, Kozlovsky A, Artzi Z, Nemcovsky CE, Moses O. Long-term biodegradation of cross-linked and non cross-linked collagen barriers in human guided bone regeneration. Clinical Oral Implants Research 2008a, 19: 295-302.

12. Moses O, Pitaru S, Artzi Z, Nemcovsky C. Healing of dehiscence type defects in implants placed together with different barrier membranes: a comparative clinical study. Clinical Oral Implants Research 2005, 16: 210-219.

13. Rothamel D, Schwarz F, Sculean A, Monika H, Scherbaum W, Becker J. Biocompatibility of various collagen membranes in cultures of human PDL fibroblasts and human osteoblastlike cells. Clinical Oral Implants Research 2004, 15: 443-449.

14. Owens KW, Yukna RA. Collagen membrane resorption in dogs. A comparative study. Implant Dentistry 2001, 10: 49-56.

15. Rothamel D, Schwartz F, Sager M, Herten M, Sculea A, Becker J Biodegradation of differently cross-linked collagen membranes: an experimental study in the rat. Clinical Oral Implants Research 2005, 16:369-378. 
16. Schwartz F, Rothamel D, Herten M, Sager M, Becker J.Angiogenesis pattern of native and cross-linked collagen membranes: an immunohistochemical study in the rat. Clinical Oral Implants Research 2006, 17: 403-409.

17. Tal H, Kozlovsky A, Artzi Z, Nemcovsky CE, Moses O. Cross-linked and non crosslinked collagen barrier membranes disintegrate following surgical exposure to the oral environment. Histological study in cat. Clinical Oral Implants Research 2008b, 19: 760-766.

18. Kozlovsky A, Abodi G, Moses O, Tal H, Artzi Z, Weinreb M, Nemcovsky CE Biodegradation of a resorbable collagen membrane (Bio-gide) applied in a double layer technique in rats. Clin Oral Implants Research 2009, Oct 20 (10): 1116-1123.

19. Schenek RK, Buser D, hardwick WR Dablin C. Healing pattern of bone regeneration in membrane-protected defects: a histologic study in the canine mandible. International Journal of Oral and maxillofacial Implants 1994, 9(1): 13-29.

20. Colangelo P, PiatteliA, Barrucci S, Trisi P, Formisano G, Caiazza S. Bone regeneration guided by resorbable collagen membranes in rabbits: a pilot study. Implant Dent 1993, 2: 101-105.

21. Zitzmann NU, Naef R, Scharer P. Resorbable versus nonresorbable membranes in combination with Bio-oss for guided bone regeneration. International Journal of Oral and maxillofacial Implants 1997, 12. 844-852.

22. Oh TJ, Meraw SJ, Lee EJ, Gianobile WV, Wang HL. Comparative analysis of collagen membranes for the treatment of implant dehiscence defects. Clinical Oral Implants Research 2003, 14: 80-90.

\title{
POREĐENJE RESORPTIVNIH MEMBRANA U VOĐENOJ KOŠTANOJ REGENERACIJI HUMANOG I BOVINOG POREKLA
}

\author{
LAZIĆ Zoran, BUBALO Marija, MILOVIĆ Radomir, MATIJEVIĆ Stevo, MAGIĆ \\ Marko, ĐORĐEVIĆ Igor
}

Svojstva membrane za vođenu koštanu regeneraciju opisali su brojni autori. Ona uključuju biokompatibilnost, odgovarajuću barijernu moć (mehaničko sprečavanje proliferacije mekog tkiva), tkivnu integraciju, imunološku inertnost, očuvanje prostora za novu alveolarnu kost i jednostavnost primene. Membrana mora da izdrži sile žvakanja i tkivne tenzije režnja, da spreči kolaps mekih tkiva i smanjenje prostora rane. Svojstvo tkivne integracije omogućava stabilizaciju rane i inhibiciju epitelne migracije.

Cilj studije je bio da ispita uticaj humane resorptivne demineralizovane membrane (RHDM) i bovine resorptivne demineralizovane membrane (RBDM) na koštanu regeneraciju i da ih međusobno uporedi.

Eksperimentalna studija rađena na 6 pasa rase nemački ovčar, sprovedena je u tri faze. U prvoj fazi izvršena je ekstrakcija drugog, trećeg i četvrtog premolara sa leve strane. Osam nedelja nakon ekstrakcije, formirana su tri defekta na levoj strani mandibule i prekrivena humanom membranom debljine $200 \mu \mathrm{m}$, bovinom membranom debljine $200 \mu \mathrm{m}$ a treći defekt je ostavljen prazan (kontrolni defekt). Patohistološka analiza 
rađena je nakon dva, četiri i šest meseci posle hirurške intervencije. U trećoj fazi uzorci koštanog tkiva podvrgnuti su patohistološkoj analizi.

Kod svih 6 pasa, defekti prekriveni humanom membranom debljine $200 \mu \mathrm{m}$, pokazali su patohistološkom analizom znatno veći stepen koštane regeneracije u poređenju sa defektima prekrivenim sa bovinom membranom i naročito sa kontrolnim defektom.

Naši rezultati su pokazali da je humana membrana pokazala najmanje prorastanje mekim tkivom i bolju koštanu regeneraciju nakon 6 meseci u poređenju sa bovinom. 